\title{
HUBUNGAN PENGGUNAAN ALAT KONTRASEPSI IUD DENGAN FLUOR ALBUS PADA IBU USIA 25-44 TAHUN ( Di Puskesmas Bacem Kecamatan Ponggok Kabupaten Blitar )
}

Apin Setyowati ${ }^{1}$, Dewanitya Wulansari ${ }^{2}$

\begin{abstract}
ABSTRAK
Keputihan atau flour albus adalah semua pengeluaran cairan alat genetalia yang bukan darah. Keputihan bukan penyakit tersendiri, tetapi merupakan manifestasi gejala dari hampir semua penyakit kandungan.Tujuan penelitian ini adalah mengetahui hubungan penggunaan alat kontrasepsi IUD dengan flour albus pada ibu usia 25-44 tahun di Puskesmas Bacem Kecamatan Ponggok Kabupaten Blitar.
\end{abstract}

Desain penelitian yang digunakan adalah kolerasi dengan pendekatan crossectional. Tempat penelitian di Puskesmas Bacem Kecamatan Ponggok Kabupaten Blitar. Populasinya adalah semua akaseptor IUD sejumlah 102 orang. Tehnik sampling yang digunakan yaitu Purposive Samplingdiperoleh 30 responden. Variabel penelitian ini adalah variabelindependen yaitu penggunaan alat kontrasepsi IUD dan variabel dependent yaitu flour albus dan pengumpulan data dengan kuesioner. Hasil penelitian ini diolah dengan cara editing, coding, scoring, tabulating. Analisa data dengan menggunakan Chi Kuadrat.

Hasil penelitian didapatkan responden yang menggunakan 28 responden (94\%), tidak menggunakan 2 responden $(6 \%)$ dari 30 responden.Penggunaan IUD yang dilihat dari buku peserta. Mengalami flour albus normal 26 responden $(86,67 \%)$, Abnormal 4 responden (13,33\%). Setelah dianalisa didapatkan hasil signifikasi $=0.507$ dengan tingkat kemaknaan 0,5 sehingga $\mathrm{H} 0$ ditolak berarti ada hubungan penggunaan alat kontrasepsi IUD dengan flour albus pada ibu usia 2544 tahun.

Berdasarkan hasil penelitian bahwa dari penggunaan IUD kebanyakan mengalami flour albus normal. Maka dari itu, disarankan akseptor yang mengalami flour albus normal harus tetap menjaga kebersihan daerah kemaluan dan tetap melakukan kontrol IUD.

Kata kunci : Penggunaan IUD, Flour Albus 


\section{PENDAHULUAN}

Keluarga Berencana ( family planning / planned parenthood ) merupakan suatu usaha menjarangkan atau merencanakan jumlah dan jarak kehamilan dengan menggunakan kontrasepsi (Sulistyawati, 2011: 13).

Indonesia merupakan Negara berkembang dengan berbagai jenis masalah yaitu ledakan jumlah penduduk yang tinggi. Melihat fenomena ini pemerintah dan masyarakat menyadari perlunya dilakukan program kependudukan dan Keluarga Berencana (KB). Berdasarkan paradigma baru visi program keluarga berencana berkualitas tahun 2015, salah satu upaya pemerintah dalam mewujudkannya adalah dengan cara penggunaan alat kontrasepsi. Metode kontrasepsi yang direncanakan efektif terdiri dari IUD, pil, suntik, dan implant. Salah satu jenis kontrasepsi efektif nasional saat ini adalah AKDR/IUD ( D3 kebidanan, 2013 )

AKDR adalah metode jangka panjang yang penggunaannya sampai 10 tahun (Saifuddin, 2006 : MK: 74). Alat Kontrasepsi Dalam Rahim (AKDR) lebih dikenal orang awam dengan istilah spiral.Pengguna AKDR saat ini cukup banyak. Menurut survey yang dilakukan jumlah akseptornya berada diposisi ketiga setelah suntik dan pil. Sebenarnya banyak keunggulan metode kontrasepsi ini, namun begitu tidak semua klien berminat dikarenakan takut efek samping , takut proses pemasangan, dilarang suami karena takut benangnya mengganggu saat bersenggama, dan kurangnya pengetahuan tentang $\mathrm{KB}$ AKDR ( Handayani, 2010: 138).

Efek samping pemasangan IUD adalah perdarahan, ekspulsi, nyeri, translokasi, infeksi, keputihan (Suratun 2013:105 . Keputihan adalah keluarnya cairan selain darah dari liang vagina di luar kebiasaan. Penyebab keputihan dapat secara normal (fisiologis) yang dipengaruhi oleh hormone tertentu. Cairannya berwarna putih, tidak berbau, dan jika tidak dilakukan pemeriksaan laboratorium tidak menunjukkan ada kelainan (Kusmiran, 2011: 21)

Keputihan dari kontrasepsi IUD merupakan keadaan yang umum, selama keputihan tidak berbau, tidak terasa gatal dan tidak terasa bau. Namun jika keputihan tidak segera ditangani maka akan terjadi dampak yang lebih serius, seperti terjadinya keputihan patologis. Penyebab paling penting dari leukorepatologik ialah infeksi. Disini cairan mengandung banyak leukosit dan warnanya agak kekuning-kuningan sampai hijau, sering kali lebih kental dan berbau. Radang vulva, vagina, serviks, dan kavum uteri dapat menyebabkan leukorepatologik (Winkjosastro, 2008:271).

Keputihan adalah semua pengeluaran cairan alat genetalia yang bukan darah. Keputihan bukan penyakit tersendiri, tetapi merupakan manifestasi gejala dari hampir semua penyakit kandungan (Manuaba,2010 : 529). Leukorea (white discharge, flour albus, keputihan) adalah nama gejala yang diberikan kepada cairan yang dikeluarkan dari alat-alat genetalia yang tidak berupa darah (Wiknjosastro,2008 : 271).Keputihan atau flour albus merupakan sekresi vaginal abnormal pada wanita (Shadine, $2012:$ 1). 
Menurut Sianturi (2004: 12), pencegahan keputihan dapat dilakukan sebagai berikut:

1) Alat pelindung

Memakai alat pelindung terhadap kemungkinan tertularnya penyakit dapat dilakukan dengan menggunakan kondom.Kondom cukup efektif menjadi benteng terhadap penularan banyak penyakit kelamin.

2) Pemakaian obat atau cara profilaksis

Pemakaian antiseptik cair untuk membersihkan liang senggama pada hubungan yang dicurigai menularkan penyakit kelamin relative tidak ada manfaatnya jika tidak disertai dengan pengobatan terhadap jasad renik penyebab penyakitnya. Pemakaian obat antibiotika dengan dosis profilaksis (pencegahan) atau dosis yang tidak tepat juga akan merugikan karena selain kuman tidak terbunuh juga terdapat kemungkinan kebal terhadap obat jenis tersebut.

3) Pemeriksaan dini

Kanker leher rahim dapat dicegah secara dini dengan melakukan pemeriksaan Pap smear secara berkala.Dengan pemeriksaan Pap smear dapat diamati adanya perubahan sel-sel normal menjadi kanker yang terjadi berangsur-angsur, bukan secara mendadak. Sebelum kanker leher rahim timbul akan melalui fase prakanker dulu angka jangka waktu yang lama dan jika tidak diobati baru gejala kanker yang sesungguhnya dapat terlihat.

\section{METODE}

Desain yang digunakan dalam penelitian ini adalah korelasional yang bertujuan untuk mengungkapkan hubungan korelatif antar variable. Dimana peneliti dapat mencari, menjelaskan suatu hubungan, memperkirakan, dan menguji berdasarkan teori yang ada. (Nursalam, 2008 : 82). Metode penelitian ini dilakukan secara crosssectional yaitu jenis penelitian yang menekankan waktu pengukuran atau observasi data variable independen dan dependen hanya satu kali pada satu saat. (Nursalam, 2008 : 83).

Variabel dalam penelitian ini variable independen adalah Penggunaan Alat kontrasepsi IUD dan variabel dependen adalah Flour
Albus Pada Ibu Usia 25-44 Tahun.Populasi dalam penelitian ini adalah semua akseptor KB IUD yang mengalami flour albus di Poli KIA Puskesmas Bacem Kecamatan Ponggok Kabupaten Blitar 102 responden.

Dalam penelitian ini menggunakan teknik purposive sampling. Jenis instrumen yang digunakan dalam penelitian ini adalah kuesioner. Kuesioner merupakan teknik pengumpulan data yang dilakukan dengan cara memberi seperangkat pertanyaan atau pernyataan tertulis kepada responden untuk dijawabnya. Analisis yang digunakan Chi Kuadrat. 
HASIL

Tabel I: Tabel Silang Distribusi Frekuensi Flour Albus Pada Ibu Akseptor IUD

\begin{tabular}{|c|c|c|c|c|c|c|}
\hline \multirow[b]{2}{*}{$\begin{array}{l}\text { Penggunaan } \\
\text { IUD }\end{array}$} & \multicolumn{2}{|c|}{ Normal } & \multicolumn{2}{|c|}{ Abnormal } & \multicolumn{2}{|c|}{ Jumlah } \\
\hline & $\mathrm{N}$ & $\%$ & $\mathrm{~N}$ & $\%$ & $\mathrm{~N}$ & $\%$ \\
\hline Menggunakan & 24 & 80 & 4 & 13 & 28 & 94 \\
\hline Tidak menggunakan & 2 & 7 & 0 & 0 & 2 & 6 \\
\hline Jumlah & 26 & 87 & 4 & 13 & 30 & 100 \\
\hline
\end{tabular}

\section{Diskusi}

Dari perhitungan statistic dengan menggunakan uji statistic Chi Kuadrat menunjukkan tingkat signifikasi lebih kecil dari alfa $0.507<0.455$ maka dapat disimpulkan bahwa $\mathrm{H} 0$ ditolak dan $\mathrm{H}_{1}$ diterima, artinya ada hubungan penggunaan alat kontrasepsi IUD dengan flour albus pada ibu usia2544 tahun di Puskesmas Bacem Kecamatan Bacem Kabupaten Blitar. Berdasarkan data pada tabel IV.9 diatas menunjukkan bahwa dari 30 responden didapatkan 24 responden $(80 \%)$ mengalami flour albus normal dan menggunakan IUD. Dan 2 responden $(6,67 \%)$ yang tidak menggunakan IUD dan mengalami keputihan abnormal 4responden (13,33\%). Dari hasil tabulasi silang tersebut dapat disimpulkan bahwa sebagian besar responden yang diteliti mengalami flour albus normal dan menggunakan IUD.

Penggunaan adalah suatu proses atau keadaan memakai untuk diambil manfaatnya Kamus besar bahasa Indonesia (2008 : 466). Keputihan adalah keluarnya cairan yang berlebihan dari liang senggama (vagina) yang menyebabkan seorang wanita acapkali mengganti pakaian dalam atau menggunakan pembalut (Sianturi, 2004: 1).

Kontrasepsi IUD merupakan metode menjarangkan atau mencegah kehamilan yang penggunaannya dengan cara dimasukkan IUD kedalam rahim ibu dan mempunyai efektifitas tinggi yaitu sampai 10 tahun. Dalam penggunaan IUD juga dapat menyebabkan flour albus, yang merupakan salah satu efek samping dari alat kontrasepsi IUD.

Data hasil penelitian pada tabel IV.9menunjukkan adanya kolerasi antara penggunaan alat kontrasepsi IUD dengan flour albus. Semakin sering ibu melakukan kunjungan ulang maka semakin besar akseptor yang mengalami flour albus normal, karena rutin melakukan kunjungan ulang dapat mendeteksi dini jika ada keluhan yang lebih lanjut.

Dari uraian diatas menyimpulkan bahwa masih ada responden yang mengalami flour albus abnormal dari penggunaan alat kontraspsi 
IUD. Penggunaan alat kontrasepsi juga harus ada dukungan dari suami dan motivasi dari tenaga kesehatan untuk rajin melakukan kontrol atau kunjungan ulang hal ini juga untuk mendeteksi adanya komplikasi yang dialami. Diharapkan dengan adanya motivasi dapat menumbuhkan akseptor untuk melakukan kunjungan ulang.

Berbagai informasi yang ada baik media cetak maupun media masa dapat dijadikan sebagai sumber untuk menambah informasi dan menambah pemahaman ibu tentang kontrasepsi IUD dan flour albus.

\section{Simpulan}

Berdasarkan penelitian yang telah dilakukan di Puskesmas Bacem Kecamatan Ponggok Kabupaten Blitar pada tanggal 01-14 Mei 2014 dari 30 responden yang dijadikan sampel penelitian dengan mengambil data melalui koesioner. Maka penggunaan alat kontrasepsi IUD dengan flour albus yang terjadi pada ibu usia 25-44 tahun di Puskesmas Bacem Kecamatan Ponggok Kabupaten Blitar dapat diambil kesimpulan sebagai berikut
Dari hasil perhitungan yang dilakukan terdapat hubungan antara penggunaan alat kontrasepsi IUD dengan flour albus pada ibu usia2544 tahun. Hal tersebut dikuatkan dengan teori yang mengatakan bahwa keputihan dapat terjadi karena benda asing dan dilihat dari hipotesi yang dipilih oleh peneliti bisa diterima.
1. Penggunaan alat kontrasepsi IUD dalam kategori menggunakan IUD 28 responden $(94 \%)$

2. Flour albus yang dialami akseptor IUD dalam kategori normal 26 responden $(86,67 \%)$

3. Ada hubungan antara penggunaan alat kontrasepsi IUD dengan flour albus berdasarkan hasil analisa $C h i$ Kuadrat, sehingga hipotesis yang dipilih oleh peneliti bisa diterima. 


\section{DAFTAR PUSTAKA}

Arikunto, Suharsimi, Prof. Dr. 2006.Prosedur Penelitian.Jakarta : PT Rineka Cipta . 2010. Prosedur Penelitian.Jakarta : PT RinekaCipta

Bahari, Hamid. 2012. Cara Mudah Atasi Keputihan.Jogjakarta : BUKU BIRU

Departemen Pendidikan Nasional. 2008. Kamus Besar Bahasa Indonesia Pusat Bahasa edisi keempat.

Handayani, Sri. 2010. Buku Ajar Pelayanan Keluarga Berencana. Yogyakarta: Pustaka Rihama

Hidayat, A. Aziz Alimul. 2010. Metode Penelitian Keperawatan dan Tehnik Analisis Data.Jakarta: Salemba Medika

IBI. 2006. 50 tahun Ikatan Bidan Indonesia Bidan Menyongsong Masa Depan: Jakarta: Pengurus Pusat IBI

Joseph, H K Dan Nugroho M S. 2010. GINEKOLOGI DAN OBSTETRI $(O B S G Y N)$. Yogyakarta :Nuha Medika

Kusmiran, Eny. 2011. Kesehatan Reproduksi Remaja dan Wanita. Jakarta: Salemba Medika: 21)

Manuaba,dr.IdaBagus Gde.2010.Ilmu Kebidanan, Penyakit Kandungan, dan $K B$ Edisi 2.Jakarta:EGC

Notoatmodjo, Soekodjo. 2010. Metodologi Penelitian Kesehatan. Jakarta: Rineka Cipta

Nursalam, 2008.Konsep dan Penerapan Metodologi Penelitian Ilmu Keperawatan. Jakarta: Salemba Medika

\section{,2011.Konsep}

Penerapan Metodologi Penelitian Ilmu
$\begin{aligned} & \text { Keperawatan. Jakarta: } \\ & \text { Medika }\end{aligned}$

Saifuddin. 2006. Buku Panduan Praktis Pelayanan Kontrasepsi Edisi 2. Jakarta : YBP-SP

.2010. Buku Panduan Praktis Pelayanan Kontrasepsi Edisi 2. Jakarta : YBP-SP

Shadine, Mohnnad.2012. Penyakit Wanita Pencegahan, Deteksi Dini \& Pencegahannya. Yogyakarta : Citra Pustaka

Sianturi, M.H.R, DSOG, MIAC. 2004.KEPUTIHAN . Jakarta: FKUI

Sugiyono, Prof. Dr.2009. Metode Penelitian Kuantitatif, Kualitatif dan $R \& D$. Bandung :ALFABETA

Sulistyawati,Ari. 2011. Pelayanan Keluarga Berencana (KB). Jakarta:Salemba Medika
Suratun, dkk, 2013.Pelayanan keluarga berencana dan pelayanan kontrasepsi.Jakarta : Trans Info Media

Uliyah, M, 2010, Awas KB! Panduan Aman dan Sehat Memilih Alat KB, Yogyakarta:PT Pustaka Insan Madani

Varney, Hellen. 2007.Asuhan Kebidanan.Jakarta:EGC

WHO.2007.Ragam Metode Kontrasepsi.Jakarta : EGC

Winkjosastro, Hanifa Prof, dr, SpOG. 2008.Ilmu Kandungan.Jakarta:YBP-SP

BKKBN, 2006.Pelayanan peserta KB aktif bulan Juni[Online] (UpdateJuni 2006)Diakses dari :http://www.bkkbn.go.id. [10 April 2014]

, (2011).Jumlah pengguna
kontrasepsi JawaTimur (Update April 2011).Diakses dari : http://www.bkkbn.jatim.go.id. [10 April 2014]

D3kebidanan, 2013. Hubungan Pengetahuan Akseptor Iud Tentang Efek Samping Alat Kontrasepsi Iud Dengan Kelangsungan Penggunaan Alat Kontrasepsi Iud Dipuskesmas [Online] (Update September 2013) Diakses dari http://d3kebidanan.blogspot.com.html. [10 April 2014]

FK UB. 2014.Angka kejadian keputihan di Indonesia [Online] (Update 2014). Diakses dari :http://old.fk.ub.ac. [14 April 2014]

Iwan, 2012.Faktor - faktor yang berhubungan dengan kejadian flour albus. [Online] (Update Agustus 2012). Diaksesdari :http://iwan-share-materi.blogspot.com .html.[10 April 2014]

Wikipedia.Ibu.[Internet]. Available from :http://id.wikipedia.org. [Accessed Ap 
